\title{
What do Intern Doctors Know about the Use of Pulse Oximetry in Pediatric Patients?
}

\author{
Intörn Doktorlar Çocuk Hastalarda Nabız Oksimetre Kullanımı ile İlgili Neler Biliyor?
}

\section{Tuğba Şişmanlar Eyüboğlu ${ }^{1}$, Okşan Derinöz Güleryüz² ${ }^{2}$ Elif Keleş ${ }^{3}$, Işıl İrem Budakoğlư}

${ }^{1}$ Department of Pediatric Pulmonology, Dr Sami Ulus Maternity and Children Research and Training Hospital, Ankara, Turkey

2Department of Pediatric Emergency, Gazi University Faculty of Medicine, Ankara, Turkey

${ }^{3}$ Department of Pediatrics, Gazi University Faculty of Medicine, Ankara, Turkey

${ }^{4}$ Department of Medical Education, Gazi University Faculty of Medicine, Ankara, Turkey

\begin{abstract}
Objective: There is no information on how the knowledge of intern doctors that will work as primary health care providers use pulse oximetry in pediatric patients. The aim of this study was to assess and compare knowledge of intern doctors on the use of pulse oximetry especially in pediatric population and factors that affect their knowledge.

Methods: A questionnaire consisting of ten questions on the use and principles of pulse oximetry were answered by intern doctors in a university hospital. A uniform answer box including possible response choices was given below each question, and subjects were asked to check the answers that they thought appropriate.

Results: A total of 204 questionnaires were analyzed. Only one of third of subjects correctly answered that pulse oximetry measures hypoxia. The known complications of the procedure were not very well known (4-21\%). Knowledge about the need for blood gases confirmation in diabetes (19\%) and venous congestion (23\%) were very low. The correct solutions were answered by $33 \%$ of subjects about inappropriate probe position and $26 \%$ about intense external light energy. The maximum score of correct answers was 22 in the questionnaire, and mean score of subjects was $12.9 \pm 0.17$. There was no correlation between age and number of departments with questionnaire scores.

Conclusions: The importance of using pulse oximetry should be emphasized. In addition, training about pulse oximetry usage in pediatric patients especially in terms of complications and limitations of devices should be increased in the undergraduate training process.
\end{abstract}

Key Words: Children, knowledge, limitations, intern doctor, pulse oximetry

Amaç: Birinci basamakta sağlık hizmeti verecek olan intörn doktorların, çocuk hastalarda nabız oksimetre kullanımı ile ilgili bilgi düzeyleri hakkında çalışma bulunmamaktadır. Bu çalışmanın amacı, intörn doktorların özellikle çocuk hastalarda nabız oksimetre kullanımı ile ilgili bilgi düzeylerinin değerlendirilmesi ve bilgilerini etkileyen faktörlerin belirlenmesidir.

Yöntem: Nabız oksimetre cihazı kullanımı ve çalışma prensipleri ile ilgili hazırlanmış on soruluk anket bir üniversite hastanesinde çalışan intörn doktorlar tarafından cevaplandırıldı. Her sorunun altında verilen olası yanıtlardan uygun olanların işaretlenmesi istendi.

Bulgular: İki yüz dört anket değerlendirildi. Nabız oksimetrenin hipoksiyi ölçtüğü katılımcıların yalnızca üçte biri tarafından doğru bilindi. Cihazın komplikasyonlarının bilinme oranı çok düşüktü (\% 4-21). Diyabet ve venöz konjesyonda kan gazı ile doğrulamanın gerekliliği ile ilgili bilginin düşük olduğu saptandı. Olgu örneklerinde uygunsuz prob yerleşiminde katılımcıların \% 33'ü ve yoğun aydınlıkta katılımcıların \% 26'sı uygun çözüm bulabildi. Ankette doğru yanıtların toplam puanı 22 iken katılımcıların ortalama puanı 12,9 \pm 0,17 'idi. Yaş ve çalışılan bölümler ile anket puanı arasında ilişki saptanmadı. Sonuç: Nabız oksimetre kullanımının önemi vurgulanmalıdır. Çocuk hastalarda nabız oksimetre kullanımı ile ilgili eğitimler yapılmalı özellikle nabız oksimetre cihazlarının kullanım kısıtlılıkları ve komplikasyonları ile ilgili eğitimler mezuniyet öncesinde arttırılmalıdır.

Anahtar Sözcükler: Çocuk, bilgi düzeyi, kısıtlılıklar, intörn doktor, nabız oksimetre

Geliş Tarihi: 15.01 .2018

Kabul Tarihi: 19.01.2018 


\section{INTRODUCTION}

The measurement of oxygen saturation is now regarded as a fifth vital sign (1). The human eye is inadequate for assessment and early detection of hypoxia. Rapid and early identification of hypoxia could prevent the development of serious complications. Pulse oximetry devices are simple, non invasive, and painless methods for monitoring oxygenation in clinical practice. It provides standard care for transport of patients in hospital or between hospitals, interventional sedation, and bedside monitoring in critical illnesses (2).

Limitations and measurement errors during the use of pulse oximetry devices are problematic and may be caused by patients or devices. Methemoglobin, carboxyhemoglobin, cyanotic heart diseases and signal disturbance due to poor perfusion, patient movement, and incorrect probe use may cause misleading pulse oximetry results (3-5). Today, pulse oximetry devices are frequently used in the monitoring of patients in many clinics. However, many physicians are unaware of the limitations of using this technology.

There are many studies measuring the level of knowledge about the use of pulse oximetry devices, which were conducted in health workers such as nurses and doctors in different areas (6-9). These studies showed significant knowledge deficits about pulse oximetry use amongst health professionals, all of whom used this technology frequently.

Pulse oximetry training is typically given during the six-year medical faculty training program. In the fourth grade pediatrics, chest disease, and 5 th grade pediatric and adult emergency internships, practical training is given. It is also expected that graduates of medical faculties will be able to use pulse oximetry at level three (practice in uncomplicated, common situations) in basic medical practice in the National Core Curriculum (10). Similarly, in different countries pulse oximetry is learned as procedural skills in undergraduate education curriculum $(11,12)$.

In this study, we aimed to collect information on the use and principals of pulse oximetry from intern doctors that will go on to work as primary health care providers in pediatric population.

\section{MATERIAL and METHODS}

In Turkey, the duration of medical education is six years. The first three years are preclinical, the fourth and fifth years are the clerkship period, and the sixth year is internship period. In the academic year 2016-2017, all 368 intern doctors were asked about their knowledge of pulse oximetry. A total of $204(55 \%)$ of them enrolled the study and demographic data were recorded. All subjects were asked about which departments they rotated in before the study. Departments were internal medicine, pediatrics, obstetrics and gynecology, general surgery, public health, emergency department, cardiology, psychiatry, and two electives.

There is no recommended or validated survey instrument on the knowledge about pulse oximetry. Therefore, a questionnaire consisting of ten questions about use and principals of pulse oximetry [what it measures, device limitations, clinical conditions, specific patient populations and solutions to the problems (two cases)] was developed by one pediatric emergency care physician, one pediatric pulmonologist, and one pediatrician.

Statistical analysis was performed using SPSS v.20.0 for Windows (SPSS Inc., Chicago, IL, USA). The chi-square test was used for nominal variables. Data are expressed as mean \pm standard error of the mean (SE). Student's t-test and One way ANOVA were used for numeric variables. A $p$-value of less than 0.05 was considered significant.

This study was reviewed and approved by institutional review board, and participation involved informed consent.

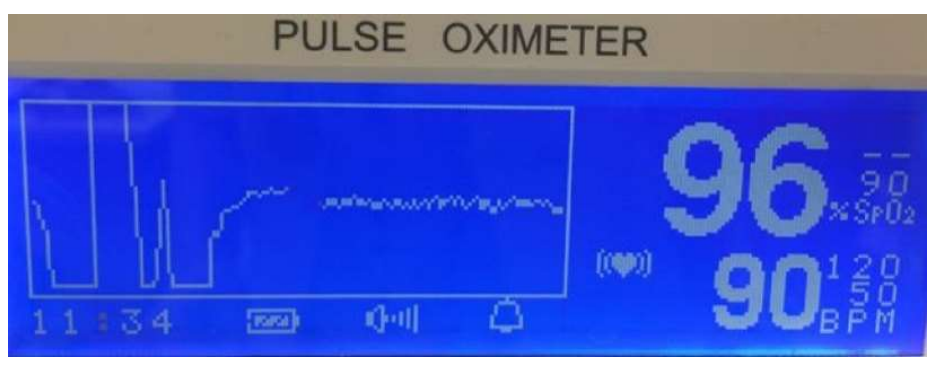

Figure 1: Abnormal waveform that is caused by inappropriate probe position.

\section{RESULTS}

Demographics and the number of studied departments by the subjects are listed in Table 1. Eighty three (40\%) of the subjects studied in both anesthesia and emergency department.

Table 1. Intern doctors demographics $(n=204)$

\begin{tabular}{ll}
\hline & $\mathbf{n}(\%)$ \\
\hline Female & $91(44.6)$ \\
Age (years \pm SE) & 23.08 \\
& 0.08 \\
Number of studied departments & \\
All & $68(33.3)$ \\
More than 4 & $73(35.8)$ \\
4 & $4(1.9)$ \\
3 & $12(5.8)$ \\
2 & $14(6.8)$ \\
1 & $42(20.5)$ \\
\hline
\end{tabular}

Answers on measurement principles, device limitations, use in specific clinical conditions, and patient populations and solutions for two case examples are shown in Table 2.

Normal lower limit of oxygen saturation in pediatric population was correctly answered by $43(21 \%)$ subjects and $79 \%$ of the subjects told that they have been trained about it. The maximum score of correct answers was 22 in the questionnaire and the mean score of subjects was $12.9 \pm 0.17$. There were no correlations between age $(r=0.075, p=0.285)$ and number of departments ( $r=-0.027, p=0.748)$ with questionnaire scores. Also, there were no statistically significance difference between gender with questionnaire scores $(p>0.05)$.

\section{DISCUSSION}

This study assesses the knowledge of intern doctors about pulse oximetry. Hypoxia is an important cause of mortality and morbidity that can be prevented. Pulse oximetry is frequently used in the pediatric area such as the delivery room, intensive care units, emergency services, and various clinics. All healthcare professionals should be familiar with the use and limitations of pulse oximetry. Also, there may be some complications from pulse oximetry such as ischemic tissue necrosis, burn and circulatory disorders when the probe is tightly connected $(3,13)$. In this study, most of the subjects $(73 \%)$ were unaware of these complications, which may lead to injuries in patients. Previous studies about the knowledge on pulse oximetry usage, especially in nurses, never addressed this issue (6-8).

Arterial blood gas analysis is a painful and invasive procedure that can lead to increased respiratory distress and deepening of hypoxia in children. Pulse oximetry devices provide a painless, non-invasive way to measure oxygen saturation. Abnormal hemoglobin molecules (methemoglobinemia and carboxyhemoglobinemia), circulatory disorders such as shock, vasoconstriction, poor perfusion due to hypothermia, and venous congestion may cause false results. Clinicians should be aware of that arterial blood gas confirmation must be performed in these situations $(2,14-18)$. Carbon monoxide poisoning is a well-known condition and most subjects answered it correctly (85\%). In diabetes mellitus, non-enzymatic glycation increases hemoglobin-oxygen affinity and elevated blood $\mathrm{HbA} 1 \mathrm{c}$ levels lead to an overestimation of oxygen saturation (19). Knowledge about it was very low in the questionnaire (19\%), and this should be emphasized in the pulse oximetry training. Knowledge rates of venous congestion (23.5\%) and shock (43.6\%) were also very low, which can cause fatal results. 
Table 2. Answers for pulse oximetry questionnaire

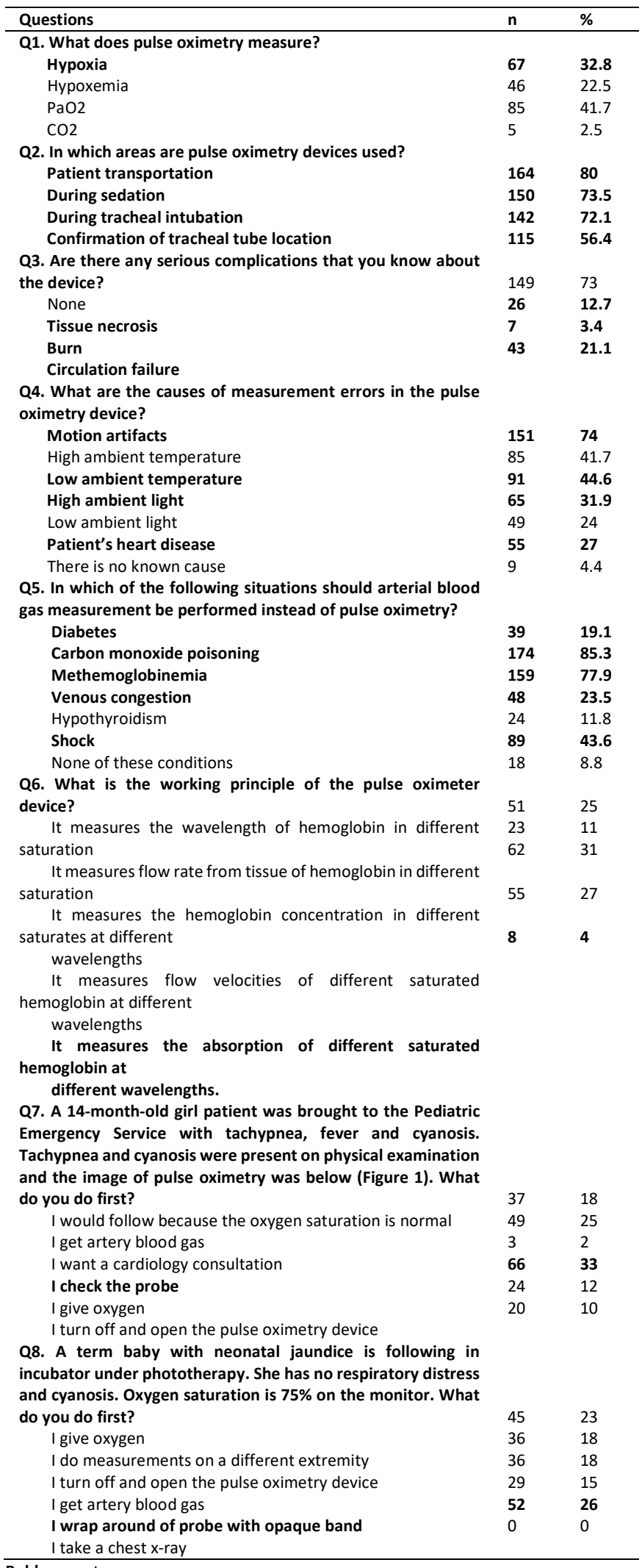

Bold, correct answers

Normal oxygen saturation limit in children may change by age and altitude $(20,21)$. Mean oxygen saturation is accepted as normal at $93-100 \%$ of moderate altitudes $(22,24)$. Only $21 \%$ of the subjects correctly answered lower limit of normal oxygen saturation in children. Not knowing the normal range may cause problems in diagnosis and treatment. However, it may cause lethal consequences. Clinicians also should be familiar with the monitoring of the devices. Distorted plethysmographic waveforms may be caused by inappropriate probe position, motion artefact, poor perfusion, irregular rhythms, and electromagnetic interference (4).
In the first scenario of the questionnaire, only $33 \%$ of the subjects correctly knew the inappropriate probe position. In the second scenario, $26 \%$ of them correctly answered about the wrapping around the probe with an opaque shield in ambient light interference. These results show that subjects did not know the measurement technique and limitations of the devices.

Knowledge rate of working principles of pulse oximetry devices has a wide range (7-72\%) in the English literature (25-29). It was found very low (4\%) in this study. Although all of the subjects were trained about pulse oximetry in medical school, only $79 \%$ of them were told that they have been trained about it, which was a remarkable result. It was thought that some of the subjects were unaware of training that they received. In the medical school training program, detailed and sufficient training with frequent updates regarding principles/applications of pulse oximetry and oxyhemoglobin dissociation curve may improve the knowledge of the intern doctors about pulse oximetry devices. Since oxygen saturation is the fifth vital sign, use of pulse oximetry must be well-known by all clinicians especially working in the emergency, intensive care unit, and delivery room. Intern doctors that will become primary health care providers should be aware of use and limitations of pulse oximetry devices.

In conclusion, oxygen saturation is very important and knowledge about pulse oximetry, especially in terms of complications and limitations, was very low in intern doctors. These results suggest that more emphasis on this topic during medical school and training fellowships are very important.

\section{Conflict of interest}

No conflict of interest was declared by the authors.

\section{REFERENCES}

1. Neff TA. Routine oximetry. A fifth vital sign?. Chest 1988;94:227.

2. Sarnaik AP, Clark JA, Sarnaik AA. Chapter 71: Respiratory Distress and Failure. In: Kliegman RM, Stanton BF, ST Geme JW, Schor NF, eds. Nelson Textbook of Pediatrics. Philadelphia, PA: Elsevier 2016:528-45.

3. Ortega $\mathrm{R}$, Hansen $\mathrm{CJ}$, Elterman $\mathrm{K}$, Woo A. Videos in clinical medicine. Pulse Oxymetry. N Engl J Med 2011;364:33.

4. Fouzas $\mathrm{S}$, Priftis $\mathrm{KN}$, Anthracopoulos MB. Pulse oximetry in pediatric practice. Pediatrics 2011;128:740-52.

5. Dieckmann RA. Chapter 1: Pediatric Assessment. In Fuchs S., Yamamoto L. APLS: The Pediatric Emergency Medicine Resource/American Academy of Pediatrics, American College of Emergency Physicians. Sudbury, United States; Jones\&Bartlett Publishers2012:2-37.

6. Seeley MC, McKenna L, Hood K. Graduate nurses' knowledge of the functions and limitations of pulse oximetry. J Clin Nurs 2015;24:3538-49.

7. Milutinović D, Repić G, Aranđelović B. Clinical nurses' knowledge level on pulse oximetry: A descriptive multicentre study. Intensive Crit Care Nurs 2016;37:19-26.

8. Kiekkas P, Alimoutsi A, Tseko F, Bakalis N, Stefanopoulos N, Fotis $T$, et al. Knowledge of pulse oximetry: comparison among intensive care, anesthesiology and emergency nurses. J Clin Nurs 2013;22:828-37.

9. Elliott $M$, Tate R, Page K. Do clinicians know how to use pulse oximetry? A literature review and clinical implications. Aust Crit Care 2006;19:139-44.

10. Gülpınar MA, Gürpınar E, Songur A, Vitrinel A. Ulusal Çekirdek Eğitim Programı, 2014. Available at: http://tip.baskent.edu.tr/kw/upload/600/dosyalar/egitim/Ulusal_ CEP.pdf. Accessed November 10, 2017.

11. Association of American Medical Colleges. Recommendations for Clinical Skills Curricula for Undergraduate Medical Education 2005 Available https://www.aamc.org/download/130608/data/clinicalskills_oct0 9.qxd.pdf.pdf.Accessed November 10, 2017.

12. Faculty Clinical Skills Working Party, University of Otago, Faculty of Medicine. Clinical Skills in the Undergraduate Medical Curriculum 2013 Available http://www.otago.ac.nz/christchurch/otago040817.pdf. Accessed November 10, 2017.

13. Mehem CC. Pulse oximetry in adults. In Uptodate web site. Available at: www.uptodate.com/contents/pulse-oximetry-inadults?source=search_result \&search $=$ pulse\%20oximetry\&selectedTitle $=2 \sim 150$. Accessed November 8 2017. 
14. Bozeman WP, Myers RA, Barish RA. Confirmation of the pulse oximetry gap in carbon monoxide poisoning. Ann Emerg Med 1997;30:608-11.

15. Tremper KK, Barker SJ. Pulse oximetry. Anesthesiology 1989; 70:98-108.

16. Van de Louw A, Cracco C, Cerf C, Harf A, Duvaldestin P, Lemaire F, et al. Accuracy of pulse oximetry in the intensive care unit. Intensive Care Med 2001; 27:1606-13.

17. Talke $P$, Stapelfeldt $C$. Effect of peripheral vasoconstriction on pulse oximetry. J Clin Monit Comput 2006; 20:305-9.

18. Haymond S, Cariappa R, Eby CS, Scott MG. Laboratory assessment of oxygenation in methemoglobinemia. Clin Chem 2005;51:434-44.

19. Pu L, Shen $Y$, Lu L, Zhang RY, Zhang Q, Shen WF. Increased blood glycohemoglobinA1c levels lead to overestimation of arterial oxygen saturation by pulse oximetry in patients with type 2 diabetes. Cardiovasc Diabetol 2012;11:110.

20. Huicho L, Pawson IG, León-Velarde F, Rivera-Chira M, Pacheco $A$, Muro $M$, et al. Oxygen saturation and heart rate in healthy school children and adolescents living at high altitude. Am J Hum Biol 2001;13:761-770.
21. Weitz CA, Garrutto RM. A comparative analysis of arterial oxygen saturation among Tibetans and Han born and raised at high altitude. High Alt Med Biol 2007;8:13-26.

22. Mau MK, Yamasato KS, Yamamoto LG. Normal oxygen saturation values in pediatric patients. Hawaii Med J 2005;64:42,44-5.

23. Balasubramanian S, Suresh N, Ravichandran C, DineshChand GH Reference values for oxygen saturation by pulse oximetry in healthy children at sea level in Chennai. Ann Trop Paediatr 2006;26:95-9.

24. Laman M, Ripa P, Vince JD, Tefuarani N. Reference values for pulse oximetry in healthy children in coastal Papua New Guinea. P N G Med J 2009;52:8-12.

25. Stoneham MD, Saville GM, Wilson IH. Knowledge about pulse oximetry among medical and nursing staff. Lancet 1994;344:133942.

26. Popovich DM, Richiuso N, Danek G. Pediatric health care providers' knowledge of pulse oximetry. Pediatr Nurs 20014;30:14-20.

27. Bilgin H, Kutlay O, Cevheroglu D, Korfali G. Knowledge about pulse oximetry among residents and nurses. Eur J Anaesthesio 2000;17:650-1.

28. Davies G, Gibson A, Swanney M, Murray D, Beckert L. Understanding of pulse oximetry among hospital staff. N Z Med J 2003;116:1-9.

29. Walters TP. Pulse oximetry knowledge and its effects on clinical practice. Br J Nurs 2007;16:1332-1340. 